Anna Gańko

Uniwersytet Warszawski

ORCID: 0000-0001-8664-455X

e-mail: anna.ganko@uw.edu.pl

\title{
Idealne ciało Berkeleya. Status ciała w filozofii percepcji George'a Berkeleya wyłożonej w Nowej Teorii Widzenia*
}

\section{Wprowadzenie}

George Berkeley jest powszechnie znany jako autor kontrowersyjnej dla wielu tezy o nieistnieniu przedmiotów materialnych. Filozof uznawany za idealistę i empirystę jednocześnie - zaprzeczający istnieniu substancji materialnej jako fizycznej podstawy świata, a równocześnie postulujący uprzywilejowaną rolę zmysłów w poznaniu rzeczywistości zewnętrznejnierzadko bywał oceniany jako ktoś, kto reprezentuje poglądy składające się na zbiór niedorzeczności. Powodowało to nietypowe formy polemiki z jego filozofia, której przykładem może być choćby słynne kopnięcie kamienia przez Samuela Johnsona ${ }^{1}$.

* Artykuł powstał na podstawie pracy magisterskiej pt. „Ucieleśnione widzenie. Rola ciała w filozofii percepcji George'a Berkeleya wyłożonej w Nowej Teorii Widzenia" napisanej pod kierunkiem dr hab. Magdaleny Bieniak-Nowak i obronionej we wrześniu 2020 roku w Instytucie Filozofii UW.

1 Więcej na temat argumentu dr. Johnsona: Harold F. Hallett, „Dr. Johnson's Refutation of Bishop Berkeley", Mind 56, 222 (1947): 132-147. 
Berkeley jako immaterialista uznaje potocznie rozumiane, fizyczne, masywne ciała za skupiska idei. Jednakże jako przedstawiciel empiryzmu wiążący poznanie ze zmysłami nie może odrzucić ciała zmysłowego poznającego.

W związku z tym Berkeley musi zmierzyć się z problemem, gdzie umiejscowić poznające zmysłowo ciało w ramach swej dojrzałej koncepcji, dopuszczającej jedynie umysły (byty całkowicie aktywne) i idee (byty całkowicie bierne). W takiej sytuacji, jak zamierzam wykazać, ciało jako narzędzie percepcji musi być przez niego utożsamione z poznającym, działającym umysłem.

W tym tekście opieram się przede wszystkim na jednym z pierwszych ${ }^{2}$ dzieł Berkeleya: Próbie stworzenia nowej teorii widzenia ${ }^{3}$ opublikowanej po raz pierwszy w 1709 roku, czyli rok przed oddaniem do druku jego największego dzieła: Traktatu o zasadach poznania ludzkiego ${ }^{4}$.

Wychodząc od zmysłu wzroku, będącego głównym tematem Próby i organizującego cały wywód, Berkeley zarysowuje swoją teorię również na znacznie wyższych poziomach ogólności - nie tylko psychologicznym, ale przede wszystkim metafizycznym i ontologicznym, które w pełni rozwija w Traktacie. Zgodnie z tym właśnie założeniem zazwyczaj podchodzi się do Próby jako do swoistego wstępu do Traktatu. Jak przyjmuje większość badaczy zajmujących się jego myśla, irlandzki filozof, pisząc Próbę, miał już zapewne w większości gotową własną koncepcję immaterializmu. Rola teorii widzenia w Berkeleyowskiej filozofii jest zatem dwojaka: z jednej strony stanowi jej samodzielną część, z drugiej strony jako dzieło skupione na węższym zakresie tematycznym stanowi sprawdzian dla całego systemu i tym samym dostarcza argumentów na jego rzecz ${ }^{5}$.

2 Wcześniej zostały wydane jeszcze rozprawki matematyczne Berkeleya: Arithmetica absque Algebra aut Euclide demonstrate (wyd. 1707), Miscellanea Mathematica (1707) oraz opublikowany w 1901 roku przez S. P. Johnstona esej Of Infinities.

$3 \mathrm{~W}$ polskiej wersji cytatów odnoszę się do polskiego przekładu przygotowanego przez Adama Grzelińskiego: George Berkeley, Próba stworzenia nowej teorii widzenia $i$ inne eseje filozoficzne, przeł. translatorium z filozofii angielskiej studium doktoranckiego Instytutu Filozofii UMK w Toruniu pod kierunkiem Adama Grzelińskiego (Toruń: Wydawnictwo Naukowe Uniwersytetu Mikołaja Kopernika, 2011). Poszczególne fragmenty oznaczam skrótem NTV (New Theory of Vision) i numerem odpowiedniego wpisu.

4 Por. John O. Wisdom, "An Outline of Berkeley's Life”, The British Journal for the Philosophy of Science 4, 13 (1953): 78-87.

5 Por. Adam Grzeliński, Człowiek $i$ duch nieskończony. Immaterializm George'a Berkeleya (Toruń: Wydawnictwo Naukowe Uniwersytetu Mikołaja Kopernika, 2010), 8; Marta Szymańska-Lewoszewska, „Miejsce teorii widzenia w filozofii 
Jednak to pierwsze dzieło irlandzkiego filozofa zasługuje na uwagę. Jak sądzę, nie tylko ze względu na to, że Berkeley antycypuje w nim rozwiązania, które w pełny sposób wyłożył w Traktacie. Godna uwagi jest tutaj nie tylko tematyka dzieła wpisująca się w nurt rozważań najważniejszych myślicieli tamtego okresu, ale też sposób wywodu prezentowany przez Berkeleya. O tym, jak przekonujący był jego wywód i jednocześnie jak kontrowersyjne były jego wnioski, mogą świadczyć słowa Jamesa Beattiego, jednego z przedstawicieli szkockiej szkoły zdrowego rozsądku, który pisał, że „zna wprawdzie wielu, którzy nie potrafią odeprzeć argumentów Berkeleya, ale nie zna nikogo, kto byłby w stanie uwierzyć w jego doktrynę"6.

Dzięki temu, że Berkeley nie skupia swojego wywodu na twierdzeniach natury ogólnej, ale na drobniejszych kwestiach i konkretnych obserwacjach, pozwala przyjrzeć się rzeczom małym - zwrócić uwagę na takie aspekty jego teorii, które mogą zgubić się w rozważaniach o większych ambicjach filozoficznych, jak te, przyświecające mu przy publikacji Traktatu. Ten aspekt Próby zamierzam wykorzystać, zadając pytanie o status ciała $\mathrm{w}$ ramach jego koncepcji. Takie podejście do jego pracy nie wydaje się niezgodne z myślą samego autora7.

George'a Berkeleya", IDEA. Studia nad Struktura i Rozwojem Pojęć Filozoficznych 26 (2014): 60.

Biorąc pod uwagę fakt, że Berkeley po wydaniu Traktatu nie odrzucił poglądów wyrażonych w Próbie - doprowadził do jej ponownego wydania i opublikował jej Obronę i wyjaśnienie, nie należy traktować tekstu Próby jako niedojrzałego dzieła, którego rozstrzygnięcia przestają obowiązywać w ramach dojrzałej koncepcji filozofa. Można potraktować Próbę jako samodzielne dzieło, a nie jako wstęp do Traktatu, ze względu na to, że skupia się na nieco innych zagadnieniach. Można też uznać Próbę za wstęp do Traktatu, ale nie w sensie niedostatków wyłożonej w nim koncepcji, a w sensie przygotowania zakładanego czytelnika do przyjęcia głoszonych przez Berkeleya tez. Ta druga możliwość jest spójna ze sposobem wywodu Berkeleya przedstawionym w Próbie. Filozof nie zaczyna od ogólnych twierdzeń, lecz od obserwacji zjawisk powszechnie znanych po to, żeby namyślając się nad nimi, stopniowo wprowadzać czytelnika w coraz bardziej teoretyczne rozważania. Dziękuję recenzentom za zwrócenie uwagi na konieczność wyjaśnienia tej sprawy.

6 Jerzy Kopania, „Semiotyka sensualizmu immanentnego. Idea, pojęcie i słowo w filozofii Berkeleya", IDEA. Studia nad Struktura i Rozwojem Pojęć Filozoficznych 3 (1990): 45.

7 W 5 paragrafie wstępu do Traktatu sam Berkeley pisze: „Albowiem ten, kto ma szerokie horyzonty, nie zawsze widzi jasno i być może ktoś bardziej krótkowzroczny, zmuszony przyjrzeć się przedmiotowi swego badania z bliska i dokładnie, będzie zdolny dostrzec to, co umknęło uwadze kogoś znacznie bystrzejszego". George Berkeley, Traktat o zasadach poznania ludzkiego, przeł. Jerzy Leszczyński (Warszawa: Państwowe Wydawnictwo Naukowe, 1956). 
Jak w takim razie należy rozumieć Berkeleyowską zmysłowość i rolę ciała w procesie poznania? Spróbuję udzielić odpowiedzi na to pytanie $\mathrm{w}$ trzech krokach: przedstawiając koncepcje umysłu prezentowane przez Berkeleya w jego zapiskach z Dzienników (1) i rozważając, która z nich jest najbardziej zbliżona do tego, co wynika z tekstu Próby (2). Następnie przyjrzę się, gdzie w ramach takiej koncepcji należy umiejscowić zmysłowe ciało (3).

\section{Umysł we wczesnej koncepcji Berkeleya. Rekonstrukcja}

Doświadczenie zmysłowe w ujęciu Berkeleya składa się w istocie z kilku równoległych względem siebie szeregów idei. Łączyć się ze sobą mogą tylko idee tego samego rodzaju (podpadające pod ten sam zmysł). Idee różnych zmysłów łączą się w umyśle dzięki doświadczeniu - w taki sposób Berkeley wyjaśnia tworzenie konglomeratów idei, które potocznie uznawane są za rzeczy zewnętrzne. Jednak poza pytaniem, jak to możliwe, że różne idee łączone są $\mathrm{w}$ jeden przedmiot, Berkeley musi zmierzyć się z kwestią jak to możliwe, że tak różne postrzeżenia łączą się w jednym podmiocie. Inaczej mówiąc, w jaki sposób umysł łączy w sobie odrębne idee.

W samej Próbie Berkeley nie podejmuje wprost tego wątku - nie jest to tematem tego dzieła. Miał się tym zająć w drugiej - nieopublikowanej części Traktatu. Jak dowiadujemy się z listów do Samuela Johnsona, ta część $w$ formie zaawansowanego manuskryptu zaginęła podczas podróży Berkeleya do Włoch w 1715 roku $^{8}$. Nigdy nie napisał jej na nowo. Dlatego Berkeleyowską koncepcję na ten temat można rekonstruować jedynie częściowo ze wzmianek $\mathrm{w}$ różnych dziełach. Jego poglądy dotyczące władz i sposobu działania umysłu znajdujemy w Dziennikach. Jednak te zapiski nie są spójne, jeśli chodzi o przedstawienie tego problemu. Jak wskazuje Piotr Szałek, Berkeley wahał się co do rozwiązania tej kwestii i skłaniał się ku trzem różnym koncepcjom 9 .

Pierwsza z nich nosi silne znamiona wpływu kartezjanizmu. Kartezjański umysł charakteryzuje się dwiema władzami: rozumem biernie odbierającym idee reprezentujące rzeczy oraz wola, przy pomocy której uznaje prawdziwość percepcji. Analogicznie do kartezjańskiego podziału

8 Piotr K. Szałek, Istnienie i umyst. Studium podstaw filozofii George'a Berkeleya (Kraków: Towarzystwo Autorów i Wydawców Prac Naukowych „Universitas”, 2016), 208.

9 Tamże. 
Berkeley wyróżnia zdolności biernego odbierania idei (moce otrzymywania myśli) oraz ich aktywnego wytwarzania (moce powodowania myśli).

Jak widać w zapiskach z Dzienników, Berkeley dostrzegł, że podział ten może doprowadzić do nowego radykalnego dualizmu: podziału na istoty całkowicie bierne i całkowicie aktywne. Dlatego w drugiej - przejściowejkoncepcji Berkeley zdaje się utożsamiać umysł z wiązką percepcji:

Umysł jest konglomeratem postrzeżeń. Usuń spostrzeżenia, a usuniesz umysł, weź ustanów spostrzeżenia, a ustanowisz umysł (PC 580 ${ }^{10}$.

Usuwa też rozróżnienie na spostrzeżenia i spostrzegający je byt:

Powiadasz, że umysł to nie spostrzeżenia, lecz owa rzecz, która postrzega. Odpowiadam: oszukują cię słowa "owa” i „rzecz”; są one mgliste, puste, pozbawione znaczenia (PC 587).

Konsekwentnie rezygnując również z reprezentacjonistycznej teorii idei - usunąwszy wcześniej rozróżnienie na postrzegane rzeczy i idee oraz usunąwszy rozróżnienie na idee oraz ich postrzeganie (utożsamiając akt postrzegania z samymi postrzeżeniami) - Berkeley utożsamia zarazem całą triadę: ideę, rzecz i postrzeganie, a więc rozum.

Przyjęcie wyłącznie takiej definicji oznaczałoby jednak pozbycie się aktywnego elementu podmiotu na rzecz jedynie biernej percepcji, na co Berkeley nie może się zgodzić, chcąc zdefiniować duchy (umysły) za pomocą ich aktywności. Dlatego też konieczne okazuje się wprowadzenie woli jako całkowicie odrębnej od rozumu tożsamego z postrzeżeniami. Jak zauważa Szałek, w kolejnym kroku wola oddzielona od rozumu utożsamiona zostaje $\mathrm{z}$ aktywnym umysłem i całkowicie oddzielona od biernej percepcji.

Takie rozwiązanie kwestii umysłu znów rodzi jednak problem dualizmu, który Berkeleyowi trudno byłoby zaakceptować. Jak słusznie wskazuje Szałek, w takim wypadku: „,umysł jako wola byłby «ślepy» i nie mógłby niczego percypować. [...] Jeśli bowiem jedynie wola jest umysłem, a w konsekwencji wola niczego nie percypuje jako «ślepa» poznawczo, wówczas umysł niczego w ogóle nie percypuje"11.

$10 \mathrm{~W}$ polskiej wersji cytatów odnoszę się do jedynego polskiego przekładu przygotowanego przez Bartosza Żukowskiego: George Berkeley, Dzienniki filozoficzne, przeł. Bartosz Żukowski (Gdańsk: Wydawnictwo Słowo obraz/terytoria, 2007). Poszczególne fragmenty oznaczam skrótem PC (Philosophical Commentaries) i numerem odpowiedniego wpisu.

11 Szałek, Istnienie $i$ umyst, 225. 
W ten sposób rozum (understanding) biernie postrzegający idee nie miałby żadnej mocy sprawczej, a wola nie miałaby żadnej idei - żadnego odniesienia do swoich aktów. Ten problem zauważa Berkeley w nocie 645:

Postrzeganie bez chcenia może istnieć. Kwestia: czy może istnieć chcenie bez postrzegania? (PC 645).

Wydaje się, że Berkeley odpowiada przecząco na to pytanie i ostatecznie zwraca się ku koncepcji umysłu, w której jest on jednym, niepodzielnym bytem, zawierającym w sobie zarówno percepcję, jak i wolę:

Wydaje mi się, że woli i rozumu oraz aktów chcenia i idei niepodobna od siebie oddzielić, że jedno żadną miarą nie może istnieć bez drugiego (PC 841).

Rekonstrukcja rozwoju koncepcji Berkeleya na temat umysłu opracowana przez Szałka pokrywa się właściwie z tą zaprezentowaną wcześniej przez Arthura Astone'a Luce'a. Luce twierdził, że na początku Berkeley skłaniał się ku monizmowi w tym sensie, że rozważał uznanie istnienia wyłącznie umysłów. W takim wypadku idee, utożsamiane przez niego wtedy z myślami, miałyby status mentalny. Następnie identyfikował umysł (duszę) i rozum (understanding) z ich zawartością, i jedno, i drugie uważał za pasywne. Po pewnych rozważaniach i wahaniach obu - umysłowi i duszy - przyznał aktywny status. Fraza „w umyśle” (in the mind) $\mathrm{w}$ pierwszych zapiskach jest zatem niedookreślona i znaczy najprawdopodobniej nie więcej niż „nie w materii” (not in matter). W kolejnym stadium oznacza „integralną część umysłu” (forming an integral part of the mind), a na koniec drugiego zeszytu „oddzielny od, ale pozostający w relacji do aktywnego umysłu" (distinct from, but in relation to, the active mind) ${ }^{12}$.

\section{Umysł w Próbie stworzenia nowej teorii widzenia}

W tym miejscu pozostaje rozważenie, która z powyżej przedstawionych koncepcji umysłu jest zgodna z tekstem Próby, a w szczególności, czy któraś z tych - dość ogólnie - zarysowanych koncepcji wyjaśnia procesy związane z poznaniem, które wiążą się z argumentami przedstawionymi w ramach Nowej Teorii Widzenia.

12 Arthur A. Luce, „Development Within Berkeley's Commonplace Book”, Mind 49, 193 (1940): 46. 
Nieczęste wzmianki na ten temat pojawiają się jedynie przy okazji omawiania innych kwestii. Umysł ${ }^{13}$ - tak jak Berkeley przedstawia w Próbie - przede wszystkim postrzega idee, zarówno proste, jak i złożone, jak np. odległość (NTV 121). Wydaje na ich temat sądy (judges) (NTV 22, 33, $38,90)$ i wyciąga wnioski (NTV 77). Idee "tłoczą się w umyśle" (crowd into mind, NTV 110) lub są w nim "odciśnięte" (imprinted in the mind, NTV 157). Jednak umysł nie tylko gromadzi idee, ale też wykonuje na nich operacje: znajduje powiązania między ideami (NTV 17) i w nim tworzą się nawykowe połączenia (NTV 21). Idee złożone są przez niego tworzone $\mathrm{z}$ danych mu idei prostych - są wprost konstruktami umysłu (creatures of mind) (NTV 109). Co więcej, to umysł doświadcza (experience) (NTV 17) i jest związany nie tylko z percepcja ale także z uczuciami: uczucia tkwią właśnie w umyśle (NTV 9).

Poza miejscami, w których Berkeley bezpośrednio odnosi się do działania umysłu, jest też kilka innych, w których mówi o poszczególnych władzach poznawczych. Nieodłącznym elementem poznawania jest u niego świadomość. Zdaniem Berkeleya nie ma ukrytych elementów w procesie poznania. Rozpatrując tezę, jakoby widzenie odległości miało odbywać się na podstawie wyznaczania kątów i linii, pisze:

Według mnie jest czymś niepojętym, jak można wydawać takie sądy i wyciagać z nich wnioski, skoro nie jesteśmy świadomi, byśmy [w akcie postrzegania] odwoływali się do tej wiedzy (NTV 19).

Postrzeżeniom towarzyszy więc zawsze świadomość ich posiadania, nie ma nic nieuświadomionego w procesie poznania. Jak wskazuje Przemysław Spryszak, dla Berkeleya mówienie o postrzeganiu nieświadomym jest jak mówienie o przedmiocie posiadającym dwie sprzeczne cechy ${ }^{14}$.

13 W polskim przekładzie Próby kilkakrotnie pojawia się termin „rozum”. Jest on tłumaczeniem angielskich fraz understanding (NTV 45, 74, 96, 130) lub mind (NTV 105). To drugie słowo z kolei we wszystkich innych miejscach tłumaczone jest jako „umyst”. Terminy te w polskim tłumaczeniu są w większości stosowane zamiennie zgodnie z treścią oryginału, w którym Berkeley nie wprowadza alternatywnej do umysłu władzy poznawczej. Angielskie reason w oryginale pojawia się tylko raz (NTV 126) w kontekście korygowania błędnego przypisywania idei odległości zmysłowi wzroku. Nie wydaje się jednak, żeby Berkeley chciał w ten sposób wprowadzić nową władzę poznawcza, jest to raczej przykład jego posługiwania się słowami również $\mathrm{w}$ potocznym sensie. W polskim przekładzie Próby słowo „rozum” pojawia się także jako odpowiednik intelligence (NTV 84) na oznaczenie bytu rozumnego.

14 Przemysław Spryszak, Filozofia percepcji George'a Berkeleya (Kraków: Wy- 
Zarysowując koncepcję idei pośrednich, Berkeley poza władzami poznawczymi związanymi bezpośrednio z postrzeganiem zmysłowym wprowadza też kolejną, którą nazywa wyobraźnią. Wyobraźnia to zdolność przywoływania przez umysł idei, które nie są aktualnie postrzegane, jest „,władzą odwzorowywania wszystkich rzeczy zmysłowych” (NTV 10). Dzięki wzrokowej idei kształtu jakiejś rzeczy jesteśmy zatem w stanie przywołać w myśli jej kształt dotykowy, mimo że nie ma pomiędzy nimi koniecznego związku. Niechętny reprezentacjonistycznym koncepcjom Berkeley nie rozważa szeroko tego, jak dokładnie miałaby działać wyobraźnia. Wiadomo, że przedmioty wyobraźni są wtórne względem przedmiotów postrzeżenia zmysłowego, wiadomo też, że zjawiają się za pośrednictwem woli poznającego podmiotu - inaczej niż postrzeżenia, które jawią mu się niezależnie od niego ${ }^{15}$.

Wydaje się, że takie działanie umysłu przybliża go do wersji przedstawionej przez Szałka jako trzeciej, dojrzałej koncepcji Berkeleya. W tym ujęciu umysł oraz jego działania stanowią jeden, niepodzielny, aktywny byt. Umysł nie tyle składa się z idei, ile je gromadzi i łączy, nadając im znaczenia, oraz operuje nimi w taki sposób, że stają się one przedmiotem działania woli. Wola - druga część aktywnego podmiotu - ponieważ nie przynależy wprost do poznania, nie jest przedmiotem zainteresowania Berkeleya w Próbie, więc pojawia się tylko w nielicznych fragmentach, w których Berkeley mówi o zjawianiu się postrzeżeń niezależnie od naszej woli (NTV 101) lub kierowaniu swoimi działaniami (NTV 147, 86). Niewątpliwie jednak jest ona integralną częścią działającego podmiotu.

Ważne, że w tym ujęciu poznanie również jest swego rodzaju aktywnością - jest nie tylko biernym postrzeganiem zmysłowym, ale też łączeniem idei prostych $\mathrm{w}$ dające się zrozumieć całości (na to wskazują np. rozważania Berkeleya dotyczące liczb (NTV 108)). Co więcej, i co bardzo istotne, poznanie jest również podporządkowane działaniu - ma służyć do rozumnego postępowania w świecie (por. NTV 86). Te dwie aktywności: doznawanie (związane z poznaniem) i działanie (związane $z$ wolą) są w gruncie rzeczy dwoma aspektami tej samej rzeczy - umysłu, który nie daje się poznać inaczej jak tylko przez nie.

Colin Turbayne twierdził, że w ostatecznej koncepcji Berkeleya słowa takie jak wola (will), rozum (understanding) i umysł (mind) należy potraktować tak samo, jak Berkeley traktuje słowa "siła”, "przyciaganie” czy „prędkość" używane przez filozofów przyrody (np. przez Newtona). Ze względu na to, że nadano im formę rzeczownikową $w$ języku, ludzie 
skłonni są rozpatrywać je jako rzeczy same, a nie jako cechy innych rzeczy. Podobnie nie należy wyobrażać sobie, że Berkeleyowskie wola, rozum i umysł to jakieś konkretne rzeczy - „części” poznającego podmiotu. Nie należy rozpatrywać ich jako rzeczy, a jako działania. W przeciwnym wypadku należałoby uznać „,substancję myślącą” za rzecz analogiczną do tej, którą eliminuje Berkeley, odrzucając pojęcie materii1 ${ }^{16}$. Taka teza znajduje potwierdzenie w niektórych z późnych wpisów w Dziennikach, np.:

Jeśli zapytacie, czym jest owa /rzecz/, która chce [wills], odpowiem, że jeśli przez słowo "rzecz" rozumiecie ideę lub coś podobnego do jakiejkolwiek idei, to twierdzę, iż żadnej rzeczy, która myśli chce [wills], w ogóle nie ma. Jakkolwiek osobliwie może to zabrzmieć, stanowi mimo to niezbitą prawdę. Owe terminy ogólne: „rzecz", , ,jest” etc., oszukują nas (PC 658).

\section{Czysty intelekt i zmysłowe ciało}

Berkeley nie rozpatruje tak rozumianego umysłu w związku z ciałem lub postrzeżeniami własnego ciała, które pojawiają się w kontekście jego rozważań dotyczących postrzeżeń zmysłowych. Co prawda Berkeley zaczyna swoje dzieło tak, jakby było z zakresu optyki, i rozważając geometryczne wyjaśnienie widzenia, zachowuje się tak, jakby odległość była linią rzutowaną na fizyczne oko, jednak robi to jedynie po to, żeby przedstawić ten punkt widzenia swojemu czytelnikowi. Wiele miejsca w Próbie Berkeley poświęca ideom dotykowym, natomiast nie kieruje uwagi ku rozstrzygnięciu tego, jaką rolę w poznaniu zmysłowym miałoby odgrywać samo ciało - ze zmysłami bezpośrednio związane. Odniesienia do ciała człowieka i doznań cielesnych pojawiają się w Próbie na cztery różne sposoby ${ }^{17}$.

16 Colin M. Turbayne, „Bekeley's Two Concepts of Mind”, Philosophy and Phenomenological Research 20, 1 (1959): 90-91.

17 W Próbie, inaczej niż w Traktacie, Berkeley zdaje się sugerować, jakoby przedmioty dotyku w odróżnieniu od przedmiotów wzroku znajdowały się w zewnętrznej wobec niego przestrzeni (m.in. NTV 43, 47, 94, 111) (por. Alan R. White, „The Ambiguity of Berkeley's «Without the Mind»", Hermathena 83 (1954): 62). Adam Grzeliński twierdzi, że „wiąże się to z początkowym wahaniem co do istnienia obiektywnej, absolutnej przestrzeni postulowanej przez Newtona” (Berkeley, Próba stworzenia nowej teorii widzenia i inne eseje filozoficzne, 107). W konsekwencji to, na co należy zwrócić uwagę, to fakt, że mówiąc „ciało” w Próbie, Berkeley inaczej będzie się odnosił do ciała poznającego (i na nim się skupiam w artykule), inaczej do ciała postrzeganego wzrokiem i jeszcze inaczej do ciała postrzeganego doty- 
Po pierwsze, odniesienie to pojawia się we fragmentach, w których Berkeley tłumaczy wzrokowe ocenianie odległości. Wspomina tam o doznaniach wynikających z obrotu oka (NTV 16, 17) lub napięcia gałek ocznych, kiedy spogląda się na przedmiot położony blisko (NTV 27). Te doznania potraktowane są jako idee dotykowe, które sugerują umysłowi odpowiednie odczytanie towarzyszących im idei wzroku.

Po drugie, ciało będące przedmiotem dotyku pojawia się jako miara odległości lub odniesienie niezbędne do określenia usytuowania przedmiotów. $\mathrm{W}$ obu tych przypadkach doznania związane $\mathrm{z}$ ciałem znów informują umysł o tym, jak powinien odczytywać towarzyszące im idee wzroku. W pierwszym przypadku idee wzroku sugerują idee dotyku, których dozna człowiek po przebyciu odpowiedniej odległości mierzonej ruchem własnego ciała, który to ruch według Berkeleya również należy do wrażeń dotykowych (NTV 45). W drugim przypadku usytuowanie przedmiotów odczytuje się w odniesieniu do usytuowania poszczególnych części ciała. Przedmioty bliższe tej części ciała, na której opiera się jego ciało, człowiek ów określiłby jako niższe, te, które usytuowane są przeciwnie, jako wyższe (NTV 93-96).

W obu wymienionych powyżej sytuacjach ciało jest traktowane nie tyle jako przedmiot zmysłowy postrzegany jako zewnętrzny wobec poznającego podmiotu, ile jako instrument poznania. Natomiast trzeci sposób, w jaki Berkeley wspomina o ciele, tyczy się doznań bólu lub przyjemności oraz działań mających na celu zachowywanie i chronienie własnego ciała przed tym, co dla niego szkodliwe, i utrzymanie się przy życiu (NTV 59, $85,147)$. W tym kontekście ciało - niezależnie od tego, czy postrzegane jako byt materialny, czy jedynie jako idea - przedstawiony jest jako integralny element człowieka. Nie jest ono wobec niego zewnętrzne, a jest postrzegane jako jego część.

Czwarty sposób, w jaki Berkeley odnosi się do ciała, dotyczy przykładu czystej inteligencji - ducha, który pozbawiony jest ciała, a więc nie posiada też żadnych idei dotyku, posiada natomiast wyraźne idee wzroku (NTV 153-159). Taki duch nie posiadałby ani idei brył, ani figur płaskich, ponieważ zarówno do wytworzenia jednych, jak i drugich potrzebna jest idea odległości. Co za tym idzie, pozbawiony byłby również idei zewnętrzności czy głębi i, w konsekwencji, przestrzeni (NTV 154). Mógłby postrzegać kolory oraz zmiany w świetle, jednak nie mógłby dokonywać żadnych - analogicznych do geometrycznych, dotyczących wielkości, proporcji itd. - operacji na tych obrazach, dlatego że te byłyby

kiem. Dziękuję recenzentom za zwrócenie uwagi na konieczność doprecyzowania wywodu w tych kwestiach. 
zmienne i ulotne. Na podstawie tego przykładu Berkeley wnioskuje, że taki duch nie mógłby posiąść żadnej wiedzy w dziedzinie geometrii, która powszechnie uznawana jest za dziedzinę dotyczącą przedmiotów wzroku (NTV 159). Co więcej, nie mając pojęcia o geometrii, nie miałby też pojęcia o żadnej przestrzeni, w której jakoby miałby się znajdować18.

Dodatkowo w całej Próbie są zawarte jedynie trzy fragmenty, które mogą jakkolwiek sugerować wątek relacji pomiędzy umysłem a ciałem postrzegającego podmiotu:

Tak więc umysł, poruszając okiem - chcąc oddalić lub zbliżyć źrenice - niezwłocznie doznaje pewnego wrażenia, a przy tym postrzega ideę odmiennej odległości, którą zwykł łączyć z tym doznaniem (NTV 17).

Oko lub, prawdę mówiąc, umysł, nawet gdy postrzega samą niewyraźność i nie rozważa jej przyczyny, stale łączy dany stopień niewyraźności z odpowiadającą jej odległością (NTV 36).

Umysł wydaje sąd na temat odległości od przedmiotu na podstawie tego, czy jego nieuzbrojone oko odbiera bardziej czy mniej niewyraźny obraz (NTV 38).

W pierwszym fragmencie umysł porusza okiem - jest władzą kontrolującą ciało, w drugim umysł jest utożsamiony z ciałem lub, mówiąc precyzyjniej, zastępuje je $\mathrm{w}$ procesie postrzegania, w trzecim - można powiedzieć, że jest „wyposażony” w ciało. To nie okiem, twierdzi Berkeley, człowiek widzi, a umysłem. Jednak żeby mogło się to wydarzyć, musi się ciałem (w tym przypadku okiem) posłużyć.

Tak niewielka liczba fragmentów, w których Berkeley wprost odnosi się do ciała, nie oznacza, że ciało nie odgrywa ważnej roli w Próbie. Berkeley nie zajmuje się nim wprost, ale nieustannie się do niego odnosi posługuje się cielesnościa, żeby przeprowadzić swój wywód. Przytoczmy pokrótce, które elementy poznanej rzeczywistości Berkeley przedstawia w taki sposób, że ciało jest w nich niezbędne.

Po pierwsze, jeśli doznania cielesne utożsamimy z ideami dotyku (a tak robi Berkeley), dostrzeżemy, że są one niezbędne do efektywnego widzenia w ogóle. Idee dotykowe (w tym doznania położenia własnego ciała i jego ruchu) są znaczeniem idei wzrokowych, tak jak przedmioty są odniesieniem wyrazów języka. Idee wzroku pouczają nas w taki sposób, żebyśmy mogli dążyć do uzyskania odpowiednich idei dotykowych,

18 Z przykładu, którym posługuje się Berkeley, wynika, że możliwe jest postrzeganie zmysłowe (w tym przypadku wzrokowe) bez ciała. Nie jest ono jednak wystarczające do łączenia tych postrzeżeń i ustalania relacji między nimi. 
które związane są też z doznawaniem bólu i przyjemności, są szkodliwe lub korzystne dla naszego ciała dotykowego.

Po drugie, idee dotykowe są niezbędne do orientowania się w przestrzeni - przez ruch własnego ciała mierzymy odległości, a przez relację idei do części własnego ciała oceniamy położenie przedmiotów. Wszelkie idee zewnętrzności są zatem ugruntowane w cielesności.

Po trzecie, geometria jako nauka jest możliwa tylko dzięki ideom dotykowym, które, jak zauważa Berkeley, w przeciwieństwie do idei wzroku są stałe.

Powyższe fragmenty wskazują na to, że poznanie w Berkeleyowskiej Próbie jest nie tylko poznaniem zmysłowym, ale też poznaniem ucieleśnionym $^{19}$. Jednak nie wskazują jednoznacznie, czym miałoby być samo ciało. Pomocne w tej kwestii zapiski można odnaleźć w Dziennikach. Berkeley, pisząc tam o ciałach, wymienia dwa ich rodzaje:

Dwojakie znaczenie [terminu] „,ciało", mianowicie: kombinacje myśli i kombinacje mocy wzbudzania myśli. Te, jak uważam, wespół z homogenicznymi cząstkami pozwolą o wiele skuteczniej odeprzeć zarzuty ze stworzenia niż założenie, że materia istnieje, /przy/ którym to założeniu, jak sądzę, odeprzeć ich nie sposób (PC 293).

Ciała etc. realnie istnieja, czy o nich myślimy, czy nie. Rozumie się je bowiem dwojako: jako zbiory myśli i jako zbiory idei mocy powodowania tych myśli. Te drugie istnieja, choć możliwe, że a parte dei stanowią jedną, prosta, doskonałą moc (PC 282).

Drugi rodzaj ciał to idee będące przedmiotem postrzeżenia zmysłowego, a zatem przedmiotem myśli w ogóle. Pierwszy natomiast, mimo że Berkeley poświęca mu tutaj mniej uwagi, interesuje nas bardziej. Ciało w tym sensie Berkeley określa jako „zbiory myśli” lub jako „kombinacje myśli", a więc rozumie je nie tyle jako podłoże procesów myślowych, ile jako same te procesy lub ich zawartość. $W$ takim znaczeniu ciało byłoby zbliżone do przejściowej koncepcji umysłu w ujęciu Szałka, w której umysł utożsamiony jest $\mathrm{z}$ wiązką percepcji. Jeśli zbiór lub kombinacja myśli jest zarazem ciałem i umysłem, trzeba dojść do wniosku, że ciało i umysł są u Berkeleya nierozróżnialne, a więc są tożsame. Biorąc jednak pod uwagę fakt, że są to dość wczesne wpisy w Dziennikach, należy przyjąć, że tak

19 Jennifer Mensch, „Embodied Cognition in Berkeley and Kant: The Body's Own Space", w: Distributed Cognition in Enlightenment and Romantic Culture, red. M. Anderson, G. Rousseau, M. Wheeler (Edinburgh: Edinburgh University Press, 2019), 88 . 
jak ewoluował Berkeleya pogląd na umysł, tak samo mogła zmienić się jego koncepcja ciała.

W Próbie ciało przedstawione przez Berkeleya jawi się dwojako. Z jednej strony pojawia się jako przedmiot postrzeżenia - Berkeley pisze o częściach ciała (własnych lub cudzych) tak, jak pisze o jakichkolwiek innych ciałach. W takim ujęciu ciało przedstawione w Próbie niewątpliwie należy zaliczyć do biernie postrzeganych przedmiotów ze wszystkimi tego konsekwencjami. $Z$ drugiej jednak strony ciało wraz z narządami zmysłów pośredniczy w procesie poznania. W takim przypadku należałoby uznać je za część aktywnego podmiotu. Umysł jako aktywny byt nie może być poznany jako idea, a jedynie poprzez działania, które są na idee nakierowane. Na tej samej zasadzie Berkeley nie prezentuje idei poznającego ciała, lecz przedstawia je przez jego działania oparte na postrzeganiu i doznawaniu. Zatem ciała w pierwszym rozumieniu - jako biernego przedmiotu - Berkeley musi się pozbyć ze swojej koncepcji, tak jak pozbywa się wszystkich innych materialnych rzeczy: redukuje je do postrzeganych zmysłowo idei. Natomiast ciała w drugim znaczeniu - jako ściśle związanego z działaniami umysłu - pozbyć się nie może.

Nie oznacza to jednak, że Berkeley zmuszony jest przyjąć jakiś rodzaj substancji, przeciw któremu występuje. Istnieje możliwość, że oczekując spójnej całości stojącej za słowem „ciało”, znów dajemy się zwieść przez słowa. Tak jak potocznie rozumiany przedmiot jest w istocie konglomeratem idei różnych zmysłów, tak ciało zmysłowe byłoby konglomeratem poznawczych władz zmysłowych. Nie jest transcendentną wobec nich podstawa, w której są ugruntowane, a zespołem odrębnych aktywności poznawczych - zdolności zmysłowego postrzegania.

„W każdym ciele są dwa nieskończone szeregi rozciągłości: jeden dotykalnej, drugi - widzialnej" (PC 61) - notuje Berkeley w Dziennikach. W odniesieniu do rzeczy poznawanych można to zdanie rozumieć jako mówiące o rozdzielnych szeregach idei różnych zmysłów. W odniesieniu do poznającego ciała zmysłowego można tu mówić o kompetencjach percypowania zróżnicowanych doznań.

W takim ujęciu poznające ciało w koncepcji Berkeleya jawi się jako nazwa zbioru aktywności umysłu związanych ze zmysłowym poznaniem. Nie jest wyróżnione ani jako odrębna od umysłu część podmiotu, ani jako władza umysłu. Jest w pełni z umysłem utożsamione i jest jedynie nazwą poszczególnych jego aktywności, w których się przejawia. 


\section{Zakończenie}

Arthur Astone Luce pisze, że „myśl Berkeleya jest jak rzeka. Niszczy materię, ale buduje zmysłowość. [...] Berkeley przywraca naszą pierwotną pewność w naszych zmysłach, upewniając nas, że to, co postrzegamy, jest nam dane, jest w naszych umysłach, jeśli to myślimy"20.

W perspektywie roli, jaką odgrywa w procesie poznania, dotyk jest dla Berkeleya jako autora Próby najważniejszym ze zmysłów. Irlandzki filozof rozumie go dość szeroko: zalicza do niego nie tylko wrażenia związane z postrzeganiem zewnętrznych przedmiotów, ale też wszelkie postrzeżenia siebie: poczucie ruchu i położenia własnego ciała, doznania bólu i przyjemności. Dzięki doznaniom cielesnym Berkeleyowski człowiek wie, jak rozumnie kierować własnymi działaniami. W Traktacie Berkeley uzupełni to wyjaśnienie o figurę Boga, który jest przyczyną wszystkich idei, w Próbie nie robi jeszcze tego kroku. Ciało jest więc traktowane przez Berkeleya w Próbie nie jako jeden ze zmysłów, ale jako władza ściśle związana z podmiotowością. Nie jest biernym odbiorcą zmysłowych doznań, ale aktywnym składnikiem poznania.

Dlatego też wspomniany na początku tej pracy Samuel Johnson, próbując obalić teorię Berkeleya przez kopnięcie kamienia, nie chciał po prostu wskazać na realnie istniejący kamień. To nie jest w żaden sposób sprzeczne z Berkeleyowską teorią. Gestem tym wskazywał na to, że zmysłowe doświadczanie nie jest tylko biernym percypowaniem - wiąże się również z działaniem i wolą. Rozpatrując zatem argument Johnsona, to nie na kamień powinno się kierować uwagę, a na niego samego. Johnson pokazuje, że ciało człowieka, który kopie kamień, to nie tylko zbiór biernie odbieranych idei, ale też działania, nad którymi człowiek ten panuje. Taki człowiek powiedziałby: „Kopnąłem kamień”, a nie: „Postrzegam, że moje ciało kopnęło kamień" 21.

Wynika z tego, że zmysłowe ciało w koncepcji Berkeleya wyłożonej w Próbie trzeba uznać za więcej niż jeden z biernych przedmiotów, których należy się wyrzec $w$ ramach immaterialistycznej koncepcji. $W$ dwoistym podziale rzeczywistości w teorii Berkeleya przedstawionej w Traktacie na byty aktywne i bierne, na postrzegające duchy i postrzegane przedmioty zmysłowe, poznające ciała zdecydowanie muszą się znaleźć po stronie tych pierwszych. Biorąc pod uwagę powyższe argumenty, Berkeley nie może rozprawić się ze zmysłowym ciałem $\mathrm{w}$ taki sposób, $\mathrm{w}$ jaki potraktował wszystkie przedmioty materialne - sprowadzić je do rangi idei.

20 Arthur A. Luce, „,Berkeley's Existence in the Mind”, Mind 50, 199 (1941): 263.

21 Hallett, „Dr. Johnson's Refutation of Bishop Berkeley”: 143. 
Tym samym musi zmierzyć się z pytaniem, jaka jest relacja takiego ciała do poznającego umysłu.

Berkeleyowskie zmysłowe ciało to nie tylko ciało doznające i postrzegające, ale też wprost ciało poznające. Jeśli zatem nie można na gruncie Berkeleyowskiego immaterializmu wyróżnić go jako części poznającego podmiotu, o którym Berkeley zdecydował, że jest niepodzielną całościa, należy utożsamić je $\mathrm{z}$ umysłem. $\mathrm{W}$ takim wypadku wszelkie postrzeżenia własnego ciała byłyby zarazem postrzeżeniami siebie poznającego podmiotu. Dążenie do zachowania własnego ciała byłoby dążeniem do zachowania siebie. A wszystkie nawyki ugruntowane w ciele byłyby przejawem uczenia się postrzegającego umysłu ${ }^{22}$.

Wspomniany wcześniej James Beattie, krytykując teorię Berkeleya, zwraca się do niego takimi słowami: „Cóż jest niewłaściwego w przekonaniu, że jeżeli spadnę w przepaść i skręcę kark, to nie będę już odtąd należał do świata żywych? Mój kark, proszę Szanownego Pana, jest być może ideą dla Pana, ale dla mnie jest rzeczywistością, i to ważną rzeczywistością"23. Nie może być w tym dalszy od prawdy - bycie ideą nie oznacza dla Berkeleya niebycia rzeczywistym; co więcej, jak Berkeley pokazuje w Próbie, ciało nie może być dla niego wyłącznie idea, ale jest czymś znacznie ważniejszym: doznania ciała są dla niego, tak samo jak idee wzrokowe, jak „,najbardziej wewnętrzne uczucie jego duszy” (NTV 41).

22 Takie postawienie sprawy rodzi kolejne kwestie do rozstrzygnięcia. Jeśli ciało zostaje utożsamione $\mathrm{z}$ umysłem, to należy uznać, że umysł jako poznające ciało jest rozciągły albo poznające ciało jako umysł jest nierozciągłe, albo ciało jest zarazem rozciągłe (jako przedmiot poznania) i nierozciągłe (jako podmiot poznania). Pierwszą z możliwości należy niewątpliwie odrzucić. Druga i trzecia z nich nie muszą być rozłączne. Ciało rozumiane jako podłoże zmysłów, które odgrywają kluczową rolę w procesie poznania opisanym przez Berkeleya w Próbie, będące władzą poznawczą utożsamioną z umysłem, rozciągłe być nie może. Jednakże ciało jako przedmiot postrzegania - składające się z poszczególnych części czy też narządów, o których Berkeley pisze (ręka, głowa, oko), musi być rozciągłe w taki sam sposób, w jaki uznajemy za rozciągłe wszystkie inne postrzegane przedmioty. Tę pozorna, jak mi się wydaje, sprzeczność, a właściwie dwoistość ciała, można tłumaczyć, jak sądzę, nieprecyzyjnością języka, w którym te same nazwy nadajemy różnym bytom, i to, jak wskazuje Berkeley, prowadzi nas niekiedy do błędów. Dziękuję recenzentom za zwrócenie uwagi na ten problem.

23 Kopania, "Semiotyka sensualizmu immanentnego”: 45. 


\section{Bibliografia}

Berkeley George. 1948-1957. The Works of George Berkeley Bishop of Cloyne. Red. A. A. Luce, T. E. Jessop. Vol. 1-9. London-Edinburgh-Paris-Melbourne-Toronto-New York: Thomas Nelson and Sons.

Berkeley George. 1956. Traktat o zasadach poznania ludzkiego, przeł. Jerzy Leszczyński. Warszawa: Państwowe Wydawnictwo Naukowe.

Berkeley George. 2007. Dzienniki filozoficzne, przeł. Bartosz Żukowski. Gdańsk: Wydawnictwo Słowo obraz/terytoria.

Berkeley George. 2011. Próba stworzenia nowej teorii widzenia i inne eseje filozoficzne, przeł. translatorium z filozofii angielskiej studium doktoranckiego Instytutu Filozofii UMK w Toruniu pod kierunkiem Adama Grzelińskiego. Toruń: Wydawnictwo Naukowe Uniwersytetu Mikołaja Kopernika.

Grzeliński Adam. 2010. Człowiek i duch nieskończony. Immaterializm George'a Berkeleya. Toruń: Wydawnictwo Naukowe Uniwersytetu Mikołaja Kopernika.

Hallett Harold F. 1947. „Dr. Johnson's Refutation of Bishop Berkeley”. Mind 56, 222: 132-147.

Kopania Jerzy. 1990. „Semiotyka sensualizmu immanentnego. Idea, pojęcie i słowo w filozofii Berkeleya". IDEA. Studia nad Struktura i Rozwojem Pojęć Filozoficznych 3: 45-67.

Luce Arthur A. 1940. „Development Within Berkeley’s Commonplace Book”. Mind 49, 193: 42-51.

Luce Arthur A. 1941. „Berkeley's Existence in the Mind”. Mind 50, 199: 258-267.

Mensch Jennifer. 2019. „Embodied Cognition in Berkeley and Kant: The Body's Own Space". W: Distributed Cognition in Enlightenment and Romantic Culture, red. M. Anderson, G. Rousseau, M. Wheeler, 74-94. Edinburgh: Edinburgh University Press.

Spryszak Przemysław. 2004. Filozofia percepcji George’a Berkeleya. Kraków: Wydawnictwo Uniwersytetu Jagiellońskiego.

Szałek Piotr K. 2016. Istnienie i umyst. Studium podstaw filozofii George'a Berkeleya. Kraków: Towarzystwo Autorów i Wydawców Prac Naukowych „Universitas”. Szymańska-Lewoszewska Marta. 2014. „Miejsce teorii widzenia w filozofii George'a Berkeleya". IDEA. Studia nad Struktura i Rozwojem Pojęć Filozoficznych 26: 59-76.

Turbayne Colin M. 1959. „Berkeley’s Two Concepts of Mind”. Philosophy and Phenomenological Research 20, 1: 90-91.

White Alan R. 1954. „The Ambiguity of Berkeley's «Without the Mind»". Hermathena 83: 55-65.

Wisdom John O. 1953. „An Outline of Berkeley's Life”. The British Journal for the Philosophy of Science 4, 13: 78-87. 


\section{Streszczenie}

Filozofia George'a Berkeleya to swoiste połączenie idealizmu i empiryzmu. Berkeley jest znany przede wszystkim ze względu na głoszoną przez siebie tezę o nieistnieniu przedmiotów materialnych. W Nowej Teorii Widzenia przedstawia natomiast proces poznania ugruntowany w percepcji zmysłowej, tym samym przyznając zmysłom uprzywilejowaną rolę w poznaniu rzeczywistości. Artykuł ma na celu próbę odpowiedzi na pytanie o status ciała i cielesności poznającego człowieka w tak zarysowanym procesie poznania w kontekście doktryny immaterialistycznej.

Proponuję takie odczytanie Próby stworzenia nowej teorii widzenia, które nie skupia się na rozumieniu jej treści w perspektywie późniejszego, uznawanego za najważniejsze dzieło Berkeleya, Traktatu o zasadach poznania ludzkiego. Zamiast tego przyglądam się tym fragmentom, w których Berkeley posługuje się pojęciami związanymi z ciałem i cielesnością - przede wszystkim ideami dotykowymi - żeby zobaczyć, jak, według Berkeleyowskiej doktryny, należy rozumieć zmysłowe ciało poznającego podmiotu.

W swojej dojrzałej doktrynie Berkeley dopuszcza istnienie jedynie dwóch rodzajów bytów: aktywnych umysłów oraz biernych idei. W związku z tym zmuszony jest zmysłowe ciało poznającego człowieka zaliczyć do jednego z nich. W pracy staram się wykazać, że nie mógł zrobić inaczej, jak utożsamić poznające ciało z aktywnym umysłem.

Słowa kluczowe: filozofia percepcji, poznanie zmysłowe, ciało, idee, doświadczenie, George Berkeley, Nowa Teoria Widzenia

\section{Summary}

\section{Berkeley's Ideal Body. Status of the Body in George Berkeley's Philosophy of Perception Presented in the New Theory of Vision}

George Berkeley's philosophy is a specific combination of idealism and empiricism. Berkeley is well known primarily for his view/theory/thesis that material objects do not exist. In the New Theory of Vision he presents a cognition process grounded in sensory perception, thus giving the senses a privileged role in cognition. The article is an attempt to answer the question about the status of the body and corporeality in such process of cognition as in the context of Berkeley's immaterialism.

I propose such a reading of the Essay of the New Theory of Vision which does not focus on its content in the perspective of the later, Treatise on the Principles of Human Cognition which is considered to be the most important of Berkeley's works. Instead, I look at those passages where Berkeley uses concepts related to the body and corporeality - primarily tactile ideas, which play a key role in the 
cognition process - to see how, according to Berkeley's doctrine, the sensual body of the perceiving person is to be understood.

In his mature doctrine, Berkeley admits the existence of only two kinds of entities: active minds and passive ideas. Therefore, the sensual body of the/a perceiving person must be classified as one of them. In the article, I argue that he could not have done otherwise than identify a perceiving body with an active mind.

Keywords: philosophy of perception, sense cognition, body, ideas, experience, George Berkeley, New Theory of Vision 